\title{
STUDI KASUS PEMBELAJARAN TARI UNTUK MENINGKATKAN KREATIVITAS DAN KEMAMPUAN SOSIAL SISWA AUTIS
}

\author{
Rita Milyartini dan Reni Haerani \\ Sekolah Pascasarjana Universitas Pendidikan Indonesia dan SMPN 18 Bandung \\ email: ritamilyartini@gmail.com
}

\begin{abstract}
Abstrak: Biasanya siswa autis dipinggirkan oleh masyarakat. Penelitian tindakan ini mencoba untuk melakukan rekonstruksi social pada seting pendidikan inklusif. Dengan menggunakan model synectic dalam belajar tari, kami mencoba untuk meningkatkan kompetensi sosial dan kreativitas siswa autis. Sintaks model ini mempunyai empat langkah, yaitu persiapan, pengenalan konsep melalui analogi dan eksplorasi, penciptaan, dan presentasi karya siswa. Setelah dua siklus, model synectic dalam belajar tari dapat meningkatkan kreativitas dan kemampuan social siswa autis. Analogi langsung, analogi personal, dan analogi konflik dapat membantu siswa autis untuk mengekspresikan gagasannya melalui gerak tubuh dan menciptakan tari dengan temannya dalam seting pendidikan inklusif.
\end{abstract}

Kata Kunci: pembelajaran tari, model sinektis, kreativitas, kemampuan sosial, autis, pendidikan inklusif

\section{A CASE STUDY ON TEACHING DANCES TO IMPROVE THE CREATIVITY AND SOCIAL COMPETENCE OF STUDENTS WITH AUTISTIC SYNDROME DISORDER}

\begin{abstract}
Usually students with autistic syndrome disorder (ASD) are marginalized by the community. This action research tried to make social reconstruction in an inclusive educational setting. By using the synectic model of learning dances, we tried to improve ASD students' social competence and creativity. The syntax of this model had four steps: preparation, introduction of the concepts through analogy and exploration, composing, and presentation of students' work. After two cycles, the synectic model of learning dances can improve ASD students' creativity and social interaction competence. Direct analogy, personal analogy, and compressed conflict analogy can help ASD students to express their idea through body movement and through creating a dance together with their friends in an inclusive educational setting.
\end{abstract}

Keywords: synectic model, creativity, social interaction, autistic, inclusive education

\section{PENDAHULUAN}

Pendidikan merupakan rekonstruksi pengalaman belajar, pembudayaan, dan pemberdayaan manusia menuju pribadi mandiri yang mampu membangun dirinya sendiri maupun masyarakat. Pendidikan dapat dimaknai sebagai proses mengubah tingkah laku anak didik agar menjadi manusia dewasa yang mampu hidup mandiri dan sebagai anggota masyarakat dalam lingkungan alam sekitar dimana individu itu berada (Sagala, 2005:3).

Kemandirian ini terbentuk melalui kemampuan berpikir nalar dan kemampuan berpikir kreatif. Pribadi mandiri nan kreatif adalah pribadi yang secara mandiri mampu berpikir, menemukan, dan menciptakan sesuatu yang baru, melihat permasalahan serta menemukan cara pemecahan baru yang bernalar dan dapat dipertanggungjawabkan.

Pendidikan seni merupakan wahana humanisasi secara konstruktif karena melalui pendidikan seni manusia diarahkan untuk sensitif, komunikatif, reflektif, dan kreatif. Sensitif yakni peka terhadap ragam fenomena kehidupan manusia maupun lingkungan. Komunikatif yakni kemampuan mengungkapkan perasaan, pikiran, dan gagasannya melalui ragam bahasa simbolik. Reflektif yakni mampu melihat kelebihan dan kekurangan diri sendiri. Kreatif menunjuk pada pengertian mampu mengolah ide dan gagasan imajinatif menjadi karya seni. 
Kreativitas menjadi salah satu ciri manusia yang berkualitas. Munandar (2009:46) mengatakan bahwa "kreativitaslah yang memungkinkan manusia meningkatkan kualitas hidupnya". Sebagai dasar dalam mencapai hal itu, diperlukan pemupukan sikap dan perilaku kreatif sejak dini. Al-Khalili (2005: 50-51) menyebutkan ada empat pilar kreativitas pada anak. "Pertama, kreativitas pada anak dapat dipicu melalui perantara yang salah satunya aktivitas seni. Kedua, anak menikmati pengalaman atau aktivitas yang berbeda. Ketiga, anak memproduksi bentuk baru, dan keempat melalui permainan".

Hawkins (2003:12) mengemukakan bahwa ada lima fase yang menggambarkan tahapan kreativitas dalam pelaksanaan pembelajaran seni tari, yakni "merasakan, menghayati, mengkhayalkan, mengejawantahkan dan memberi bentuk". Pada fase merasakan, anak belajar melihat, menyerap fenomena berdasarkan penginderaan, hingga menyadari adanya sensasi dalam diri akibat penginderaan. Fase menghayati yakni menggunakan perasaan untuk memahami temuan hasil pengamatan terhadap kehidupan, dan menjadi sadar akan sensasisensasi dalam tubuh. Fase mengkhayalkan yakni berkhayal tentang masa lalu, membebaskan proses berfikir agar khayalan muncul dan berkembang, serta menggunakan khayalan dan daya imajinasi sebagai alat penemuan. Fase mengejawantahkan yakni menghubungkan khayalan dengan kualitas estetis sehingga dapat diwujudkan dalam ide gerak yang melampui pengalaman awal. Fase memberi bentuk yakni meluncurkan ide, menggabungkan unsur estetis hingga berwujud gerak yang merupakan metafora pengalaman batin.

Berdasarkan pernyataan di atas sangat jelas bahwa pendidikan seni tari berperan penting dalam proses pengembangan kreativitas. Solusi yang harus dilakukan guru adalah menemukan cara pembelajaran seni tari yang mampu memotivasi siswa untuk bersikap kreatif. Kreativitas siswa termasuk siswa autis perlu dikembangkan. Pemilihan model pembelajaran merupakan salah satu upaya untuk merangsang keaktifan dan kreativitas siswa agar ia dapat belajar dengan lebih baik. Lalu model pembelajaran bagaimanakah yang harus dipilih untuk merangsang aktivitas dan kreativitas siswa dalam pembelajaran tari?

Salah satu model pembelajaran yang dapat digunakan untuk mengembangkan kreativitas siswa dalam bidang bahasa adalah model sinektik (synectics). Sinektik merupakan model yang dapat diaplikasikan dalam pembelajaran untuk meningkatkan kreativitas baik secara individual ataupun kelompok. Selain itu sinektik melatih siswa mengembangkan kemampuan imajinasi melalui bermain analogi dalam proses berkreativitas.

Model pembelajaran sinektik tampaknya belum banyak diterapkan dalam ilmu-ilmu sosial (termasuk dalam pembelajaran seni tari). Oleh karena itu, model pembelajaran sinektik ini perlu diujicobakan pengembangan dan efektivitasnya dalam meningkatkan kreativitas siswa pada pembelajaran seni tari. Model ini menekankan kegiatan pembelajaran yang berpusat pada siswa, dan menggunakan multi stimulus sesuai modalitas belajar peserta didik.

Pendidikan bagi semua termasuk anak autis merupakan amanah Unesco yang memerlukan tindak lanjut. Berdasarkan peraturan Menteri Pendidikan Nasional No. 70 tahun 2009, tanggal 5 Oktober 2009 bahwa pendidikan inklusif merupakan pendidikan bagi perserta didik yang memiliki kelainan dan memiliki potensi kecerdasan dan/atau bakat istimewa. Dalam UU SISDIKNAS No. 20 tahun 2003 pasal 15 dijelaskan bahwa pendidikan khusus merupakan pendidikan untuk peserta didik yang berkelainan atau peserta didik yang memiliki kecerdasan luar biasa yang diselenggarakan secara inklusif atau berupa satuan pendidikan khusus. Berdasarkan dua produk hukum tersebut, maka siswa autis sebagai bagian dari siswa berkebutuhan khusus memiliki hak untuk memperoleh layanan pendidikan baik dalam satuan pendidikan khusus maupun secara inklusif di sekolah umum.

Kehadiran siswa autis di sekolah umum seringkali menimbulkan persoalan bagi siswa lain, maupun guru. Terlebih bila sekolah belum memiliki guru-guru yang memahami karakteris- 
tik siswa autis. Dampaknya seringkali siswa autis memeroleh perlakuan diskriminatif dan terpinggirkan dalam pergaulan sosial. Persoalan ketidakmampuan untuk berkomunikasi dan berinteraksi sosial yang dihadapi oleh siswa autis dapat semakin diperkuat, bila sekolah inklusi tidak memberinya ruang dan lingkungan belajar yang baik.

Model ini diharapkan mampu menjadi salah satu solusi bagi upaya mengembangkan kemampuan interaksi sosial siswa autis dengan siswa normal lainnya dalam konteks pendidikan inklusi. Hal tersebut dalam tari dapat dilaksanakan melalui analogi personal (personal analogy) yakni keterlibatan empati siswa untuk berperan sebagai sesuatu melalui sebuah gerakan tari, analogi langsung (direct analogy) membandingkan secara langsung berdasarkan pengamatan misalnya mengekspresikan gerak keseharian dalam berjalan atau berlari, dan analogi konflik padat (compressed conflict analogy) yakni menganalogikan dua keadaan atau sifat dari sesuatu yang berlawanan, misalnya dalam tari mengekspresikan gerak semut yang lelah dan semut yang bersemangat. Ketiga analogi dapat dikolaborasi dan dikembangkan dalam pembelajaran tari yang bersifat kelompok maupun individual.

\section{METODE}

Penelitian ini menggunakan action research dengan subjek tunggal. Kasus yang dikaji terkait perkembangan kemampuan interaksi sosial dan kreativitas seorang anak autis di SD inklusi. Subjek penelitian yakni siswa autis bernama IZ yang memiliki interaksi sosial minim dan kurang mampu berinteraksi secara timbal balik. Ia lebih suka menyendiri, menghindari kontak mata, ekspresi wajah datar dan tidak berbaur dengan teman. Respon dalam menanggapi guru juga sangat minim sehingga harus dipanggil berulang-ulang. Ia kurang mampu berkomunikasi dengan indikasi berkata seperlunya, hanya dua atau tiga kata yang diucapkan.
Canggung dalam melakukan gerakan serta berperilaku agak aneh. Ia terlihat sering menggoyang-goyangkan badan dan mengulang-ulang kata sambil berjalan.

Rencana tindakan disusun berdasarkan model pembelajaran seni berbasis sinektik yang telah disusun oleh Masunah dkk (2011:136). Konsep tari yang dipelajari siswa yakni tenaga (tenaga kuat, ringan dan mengalir) dan tempo (tempo cepat dan lambat). Konsep tari ini dikemas dalam pembelajaran dengan tema tentang semut. Semut merupakan contoh binatang yang mampu bekerjasama dalam hidup. Melalui kegiatan berkreasi tari dengan tema semut diharapkan siswa autis dapat bekerjasama dengan siswa lainnya.

Sintaksis terdiri dari tahap persiapan, pengenalan konsep, eksplorasi melalui bermain analogi, berkreasi dan presentasi hasil karya. Seperti tergambar dalam bagan 1 .

Pada tahap persiapan dilakukan olah tubuh, dan penggalian pengetahuan awal siswa tentang ciri-ciri kehidupan semut melalui stimulus boneka semut. Pada pengenalan konsep dilakukan penjelasan terkait unsur tenaga melalui diskusi dan demonstrasi. Siswa juga diminta menuliskan ragam gerak yang telah dipraktikkan di papan tulis. Tahap eksplorasi melalui analogi dimulai dengan analogi langsung, analogi personal, dan analogi konflik. Tahap selanjutnya adalah tahap kreasi dimana siswa diminta berdiskusi dalam kelompok untuk menyusun gerak dalam satu kesatuan. Sintaksis persiapan hingga berkreasi diulangi untuk pengenalan konsep tentang tempo. Tahap terakhir yakni presentasi hasil karya siswa secara berkelompok.

Kegiatan dirancang dalam empat kali pertemuan, dimana observasi dan refleksi dilakukan di akhir setiap pertemuan. Siklus kedua dimulai bila hasil refleksi menyepakati perlunya perubahan strategi untuk mencapai hasil yang diharapkan. Agar lebih jelas perhatikan alur penelitian tindakan berikut. 


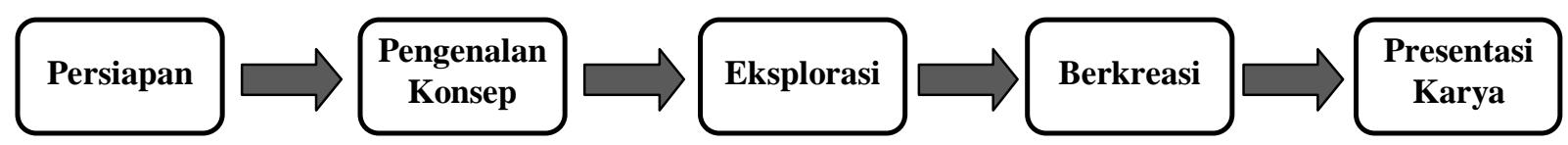

Bagan 1. Sintaksis Model Pembelajaran Seni Bagi Siswa Berkebutuhan Khusus (Masunah dkk, 2011:136)

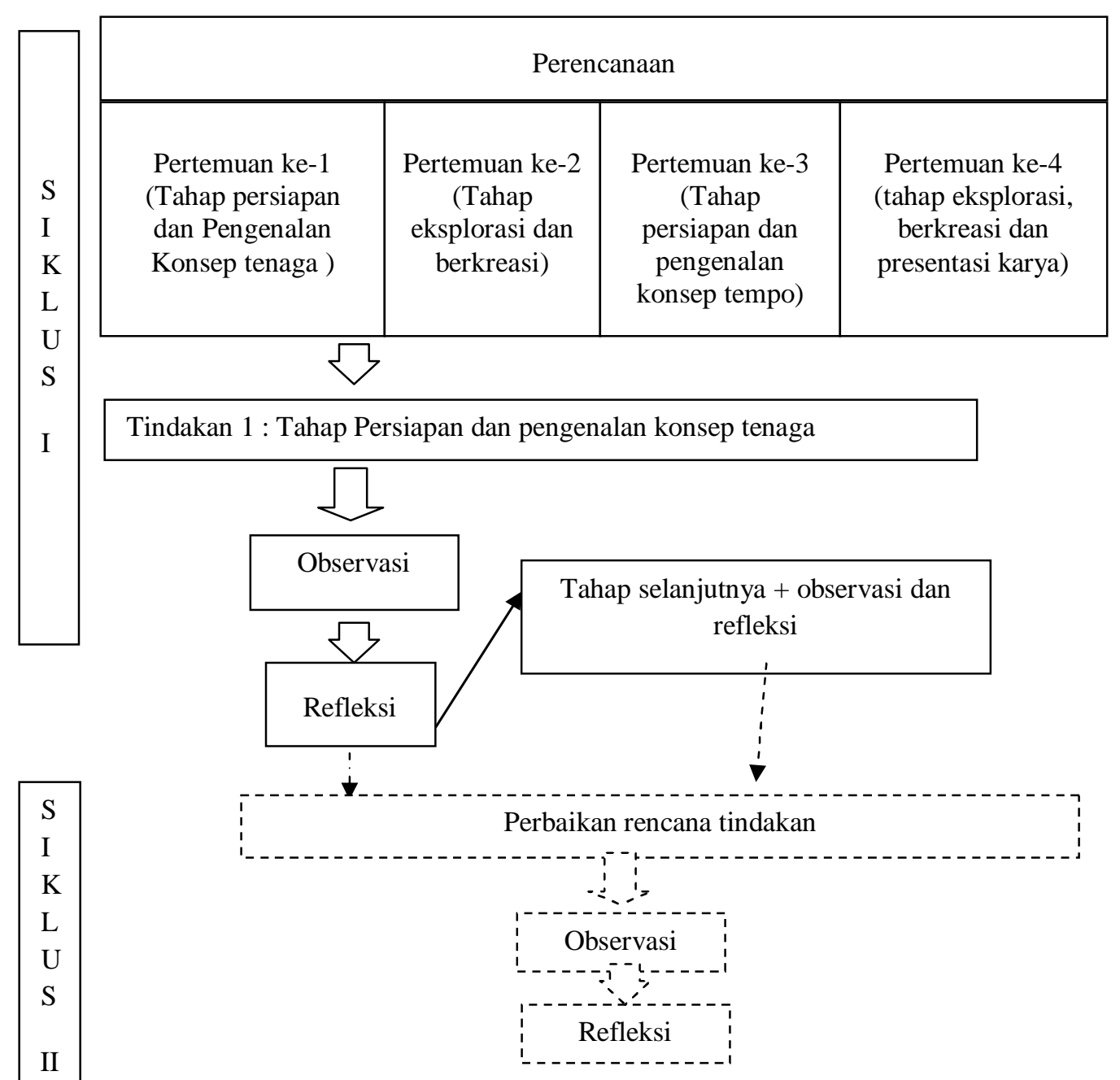

Bagan 2. Desain Penelitian Tindakan

Proses pengumpulan data dilakukan dengan cara observasi, wawancara, studi dokumen dan focus group discussion (FGD). Observasi dilakukan terhadap proses pembelajaran, perkembangan kreativitas dan kemampuan sosial siswa autis maupun siswa non autis. Wawancara dilakukan pada siswa non autis maupun siswa autis, dan guru seni budaya SD Al Mabrur yang menjadi mitra penelitian. Studi dokumen dilakukan terhadap catatan perkembangan siswa yang dimiliki sekolah dan hasil penilaian kelompok. FGD dilakukan bersama para ahli pendidikan luar biasa, ahli pendidikan tari, guru tari, dan guru SLB. FGD dilakukan untuk memperoleh masukan terhadap rancangan tindakan, model yang dihasilkan, perkembangan kreativitas dan kemampuan sosial siswa autis dalam setting inklusi.

Indikator penilaian tentang kreativitas yakni: (1) memiliki gagasan /ide original dalam mengungkapkan unsur gerak tari (tenaga dan tempo); (2) Kemampuan mengembangkan ga- 
gasan atau ide terkait unsur gerak; (3) Memiliki antusias dalam melakukan eksplorasi gerak melalui analogi; dan (4) memiliki daya imajinasi yang baik. Indikator lain yang diamati adalah kemampuan berinteraksi, meliputi: (1) mengikuti instruksi guru; (2) bertatap muka dengan teman; (3) berbaur dengan teman dan (4) respon terhadap pembelajaran.

Indikator selanjutnya yang diamati yakni kemampuan bekerjasama, meliputi: (1) Keterbukaan dengan teman terhadap sesuatu yang baru; (2) bekerjasama dan bertanggung jawab dalam mengerjakan tugas bersama teman; (3) ikut terlibat dalam identifikasi gerak; (4) menyesuaikan diri dalam situasi kebersamaan. Indikator aspek terakhir yang diamati berkaitan dengan kemampuan empati, yakni: (1) mengerti perasaan orang lain dan membantu teman yang kesulitan; (2) tertarik untuk belajar bersama teman; (3) merasa senang mengikuti pembelajaran tari; (4) bersikap terbuka dan menerima keberadaan kondisi teman

Penelitian tindakan ini dilakukan di SD Al Mabrur Bale Endah Bandung, dalam dua siklus. Pada siklus pertama (tahap persiapan) respon siswa terhadap stimulus boneka untuk mengungkapkan konsep tenaga pada tari belum memenuhi harapan. Sebagian siswa termasuk siswa autis masih terlihat bingung. Oleh karena itu, pada siklus dua digunakan stimulus gambar semut yang membawa beraneka beban, seperti membawa apel dan membawa sepotong kecil kue.

Analisis data dilakukan dengan cara melakukan triangulasi. Pada setiap refleksi dilakukan triangulasi atau membandingkan data hasil observasi, hasil wawancara dan studi dokumen untuk diperoleh kesimpulan sejauh mana tindakan yang direncanakan dapat mencapai tujuan yang diharapkan.Interpretasi hasil penelitian siklus pertama hingga siklus kedua, dibahas kembali dalam FGD untuk mendapat masukan.

\section{HASIL DAN PEMBAHASAN Hasil}

Setelah dilakukan penelitian diperoleh data bahwa model pembelajaran seni berbasis sinektik dapat digunakan untuk meningkatkan kreativitas dan interaksi sosial siswa autis dalam pembelajaran tari. Aplikasi model ini menggunakan pendekatan pembelajaran kooperatif dan kontekstual. Prinsip pembelajaran kooperatif yang menekankan usaha bersama dan kemandirian individu, telah memberikan peluang pada siswa autis dan siswa lainnya untuk berbagi ilmu, bertanggung jawab pada tugas masing-masing dan saling berempati terhadap kekurangan teman. Pembelajaran kontekstual ditandai oleh pemilihan materi pelajaran berdasarkan fenomena yang dapat dijumpai anak dalam kehidupan mereka sehari-hari. Baik secara individu maupun berkelompok, siswa diminta mengungkapkan dan mengembangkan ragam gerak berdasarkan pengalaman pribadinya. Dalam proses belajar, siswa diarahkan untuk melakukan kerjasama dalam menghasilkan kreasi gerak dan presentasi karya.

Sintaksis model terdiri dari lima tahap yakni persiapan, pengenalan konsep, eksplorasi, kreasi, dan presentasi karya. Pada tahap pengenalan konsep ditemukan bahwa analogi langsung lebih mudah untuk dipahami siswa. Sementara analogi personal dan analogi konflik padat cocok digunakan untuk membantu siswa mengembangkan gagasan/ ide gerak pada tahap eksplorasi dan kreasi. Tahap presentasi karya dapat dilakukan setelah siswa secara berkelompok mampu merangkaikan ragam gerak semut dengan variasi tenaga dan tempo.

Unsur pendukung yang penting diperhatikan dalam implementasi model ini yakni media berbentuk benda atau gambar sebagai stimulus untuk melakukan imajinasi. Stimulus boneka untuk membantu siswa berimajinasi tentang gerakan semut terbukti sulit dipahami siswa. Sewaktu ditanya bagaimana gerakan semut kalau membawa makanan? Siswa sulit untuk berekspresi. Stimulus berupa gambar semut yang sedang membawa apel, kue, atau bijibijian ternyata lebih mudah dipahami siswa untuk mengekspresikan konsep tenaga pada tari. Di samping itu, juga diperlukan ruang yang cukup untuk bergerak, bila tidak ada ruang khusus, maka meja dan kursi di ruang kelas harus digeser ke pinggir. 
Sistem sosial yang perlu dibangun adalah sikap saling menghargai dan mencoba untuk mengerti perbedaan. Guru berposisi sebagai fasilitator dan motivator yang berupaya menjalin komunikasi melalui penerapan nilai kasih sayang, dan kooperatif terhadap semua siswa. Siswa autis memerlukan penanganan dengan kasih sayang, yang dapat diwujudkan guru dalam bentuk bimbingan individual saat siswa menghadapi kesulitan, bujukan yakni mengelus kepala dengan lembut saat siswa gelisah dan dorongan untuk melakukan kerja kelompok. Siswa lain dibimbing untuk menerima perbedaan dan menghargai kelebihan serta kekurangan masing-masing.

Temuan lain yakni terkait perkembangan kreativitas dan interaksi sosial siswa autis. Pada awal pertemuan pertama siswa autis belum mampu berinteraksi, baik dengan guru maupun sesama teman. Ia cenderung memisahkan diri, lebih banyak diam dan jarang berkomentar. Sikapnya tak acuh dan kurang berpartisipasi dalam proses pembelajaran. Interaksi mulai muncul setelah dilakukan olah tubuh pada tahap persiapan. Sesekali ia tersenyum, mau melakukan kontak mata dan mengikuti perintah guru. Tahap persiapan yang melibatkan aktivitas gerak pemanasan tubuh secara bersama-sama membantu seluruh siswa termasuk siswa autis untuk berkonsentrasi pada pelajaran tari.

Pada tahap pengenalan konsep siswa diminta mengidentifikasi aktivitas sehari-hari yang menggunakan tenaga kuat, sedang dan ringan, serta menuliskannya di papan tulis. Guru kemudian menunjukkan boneka semut dan meminta siswa mengekspresikan gerak tubuh mengimitasi gerak semut yang membawa makanan (analogi personal). Reaksi seluruh siswa masih bingung. Lalu guru memperjelas instruksi melalui gambaran kehidupan yang nyata berdasarkan pengalaman tubuh saat membawa beban berat dan ringan. Setelah guru mengibaratkan gerak tubuh manusia membawa beras sekarung, maka siswa dapat melakukan gerak dengan tenaga kuat (analogi langsung). Siswa autis semula mengasingkan diri, tetapi tiba-tiba tanpa disuruh ia mendemonstrasikan gerak tenaga kuat. Guru bertanya gerak apa itu?
Ia menjawab "mendorong mobil". Guru melanjutkan pertanyaan, " kalau mendorong mobil IZ menggunakan tenaga apa?" IZ pun menjawab "tenaga kuat".

Guru kemudian mengenalkan konsep ragam tenaga melalui cerita pengurangan beban yang dibawa tubuh. Semua siswa dapat memahami konsep ragam tenaga (kuat, ringan, dan mengalir) saat mereka mengekspresikannya dalam gerak tubuh. Satu persatu siswa dibimbing untuk mengekspresikannya termasuk siswa autis.

Pertemuan dua merupakan pengulangan tahapan belajar karena kegiatan belajar tertunda satu minggu oleh kegiatan ujian tengah semester. Hasil refleksi pertemuan pertama menjelaskan bahwa penggunaan boneka semut sebagai stimulus kurang membantu siswa untuk mengekspresikan tenaga, di samping itu pembelajaran individual kurang membantu siswa autis dalam berinteraksi, walaupun demikian terlihat kreativitas mulai terbangun. Oleh karena itu, diputuskan untuk mengulang materi agar siswa lebih memahami penggunaan tenaga kuat, ringan dan mengalir.

Pada pertemuan kedua, Setelah olah tubuh selesai siswa diminta membentuk kelompok. Siswa diinstruksikan untuk melakukan gerak tubuh dengan ragam tenaga. Belajar kelompok ini bertujuan untuk lebih memperjelas pengamatan terhadap interaksi antar siswa. Saat belajar kelompok terlihat siswa autis mampu berbaur dalam kelompok, namun sesekali siswa tersebut menghindar dari kelompok dan mendekati guru tanpa mengucapkan sepatah katapun.

Guru kemudian menjelaskan pada seluruh siswa bahwa dalam gerak taripun diperlukan ragam tenaga seperti gerakan tubuh saat membawa beban ringan dan beban berat (analogi langsung). Saat guru menjelaskan siswa autis terlihat sedikit berkonsentrasi, tetapi ekspresi wajahnya masih datar. Selanjutnya siswa secara individu dan kelompok diminta meragakan gerak kaki dan tubuh sebagai ekspresi tenaga kuat dan tenaga ringan.

Setelah siswa terlihat mampu melakukannya, guru meminta mereka menganalogikan ge- 
rakan semut dengan tenaga kuat, sedang, ringan, dan mengalir. Kegiatan ini masih dilakukan dalam kelompok. Tiba-tiba ada seorang siswa berkebutuhan khusus lain yang mengalami gangguan emosional (emotional behavior disorder $=E B D)$ memukul pembatas kelas hingga guru dan siswa lain kaget. IZ bereaksi dengan berkata pada guru bahwa yang memukul adalah FR (siswa EBD). Guru berupaya menenangkan siswa dengan kasih sayang, dan membagi perhatian dengan seimbang.

Pada tahap eksplorasi siswa dibimbing untuk menemukan sendiri ekspresi gerak semut melalui analogi personal dan konflik. Analogi personal anak-anak diminta meragakan semut yang membawa makanan. Bagaimana gerak kakinya, tangannya, kepalanya, ekspresi wajahnya dan lain-lain. Siswa juga distimulus menggunakan analogi konflik, dengan meminta mengekspresikan gerak bila semut membawa makanan dalam jumlah besar dan dalam jumlah sedikit. IZ mengalami perkembangan kemampuan berinteraksi terutama pada saat kerja kelompok. IZ mau melakukan instruksi guru untuk mendemonstrasikan gerak bersama temantemannya. Tetapi ia kurang bersemangat karena teman-teman memposisikannya di urutan belakang.

Pertemuan ketiga IZ tidak hadir. Pada pertemuan keempat guru membuka pelajaran dan menyampaikan tes lisan untuk mengetahui pemahaman siswa terhadap materi sebelumnya. Setiap siswa diminta mengidentifikasi aktivitas semut dan memperagakan tenaga dengan hentakan kaki dan tempo dengan hitungan tu-waga- dst. Guru meminta IZ memperagakan ragam tenaga yang telah dipelajari dua minggu sebelumnya. IZ langsung berdiri dan memperagakan gerak dengan tenaga kuat, sedang, dan ringan. Saat IZ memperagakan gerak, guru mengarahkan IZ tentang penggunaan tempo dengan mengucapkan hitungan tu-wa-ga- dan seterusnya.

Sebelum memasuki tahap selanjutnya, seperti biasa guru mengajak siswa melakukan olah tubuh. Walaupun baru sembuh dari sakit, IZ terlihat bersemangat mengikuti kegiatan olah tubuh. Ia menghitung dengan suara keras, sambil menirukan gerakan yang dicontohkan guru.

Pada pertemuan keempat kemampuan berinteraksi IZ mengalami peningkatan yang baik, ia mampu berbaur dengan teman dan berkomunikasi dengan guru. IZ mampu mengerjakan tugas menyusun gerak kreasi dan mengikuti alur diskusi bersama teman kelompoknya. Pada tahap ini secara bergantian setiap kelompok diminta menampilkan hasil kreasinya. IZ selalu ingin dekat dengan guru dan melibatkan diri saat guru menghitung ketukan dalam tempo lambat dan cepat. Akhirnya IZ yang memberi aba-aba memulai dan memberhentikan ketukan. IZ juga yang menyuruh kelompok lain untuk tampil berikutnya. Hal ini menunjukkan adanya inisiatif dalam berkomunikasi dan adanya empati terhadap guru yang terlihat lelah.

\section{Pembahasan}

Safaria (2005:1), Veskarisyanti (2008: 17), Prasetyono (2008:148) dan Delphie (2009: 4) menjelaskan bahwa autism atau autisme dilandasi oleh adanya gangguan neurobiologis yang dimulai pada usia anak, berdampak pada gangguan perilaku, interaksi sosial, bahasa dan komunikasi. Oleh karena itu, seorang anak autis terlihat sering melakukan gerak motorik yang diulang-ulang, cenderung menyendiri, seolah asyik dalam dunianya sendiri.

Berdasarkan hasil penelitian dijelaskan bahwa kesulitan berinteraksi sosial yang dihadapi anak autis dalam lingkungannya dapat diatasi melalui penerapan model pembelajaran tari berbasis sinektik. Kita melihat bila semula IZ sering memisahkan diri dari teman-temannya, sulit berbaur, tidak mau menatap mata dalam berkomunikasi, hanya mengatakan sepatah dua patah kata, dan cenderung pasif dalam berkomunikasi ternyata ia mengalami perubahan kemampuan berinteraksi sosial. Perhatian dan pendekatan kasih sayang yang ditampakkan guru pada siswa autis maupun siswa lainnya, mampu menjadi landasan untuk mengembangkan kepercayaan sekaligus motivasi untuk berkomunikasi pada siswa autis.

Stimulus berupa gambar semut yang diikuti oleh pertanyaan terkait cara mereka hidup 
dan bergerak, mampu menstimulus anak untuk bergerak sambil berimajinasi. Pembelajaran kooperatif dalam mengekspresikan gerak dan berkreasi gerak mampu membantu siswa untuk saling perduli dan bekerja sama. Sebagai contoh pada tahap eksplorasi siswa dibimbing untuk menemukan sendiri ekspresi gerak semut melalui analogi personal. Saat analogi personal anak-anak diminta meragakan semut yang membawa makanan. Anak-anak bergerak seolah menjadi semut. Bagaimana gerak kakinya, tangannya, kepalanya, ekspresi wajahnya, dan lain-lain.

Keterlibatan siswa autis dalam kegiatan kelompok sesuai dengan pendapat Zhang \& Griffin berikut ini: However, when teachers offer individualized instruction, students with autism are more likely to participate in physical education class activities... To help individualize instruction, teachers should offer physical activities that allow children to select their own participation level based on their activities. (Zhang \& Griffin, 2007:34)

Di sini dijelaskan bahwa seorang anak autis lebih memilih aktivitas kelas daripada individual bila guru menawarkan pilihan. Ia juga mengatakan sebaiknya dalam proses belajar disediakan kemungkinan pilihan gerak sesuai kemampuan masing-masing anak.

Merujuk pendapat tersebut, setiap siswa diberi kesempatan untuk mengekspresikan tubuh sesuai imajinasinya masing-masing. IZ (siswa autis) mampu melakukan gerak dengan konsep tenaga kuat melalui gerak langkah kaki yang berat, tenaga ringan melalui gerak langkah kaki meloncat-loncat kecil, dan mundur dengan cepat, serta tenaga mengalir melalui gerak langkah kaki tak berhenti. Namun untuk gerakan tangan, dia baru mampu melakukan dua variasi gerak yakni gerak tangan diputar ke belakang dan kedua tangan disatukan mengepal. IZ akan sigap melakukan instruksi guru, bila namanya dipanggil, namun segera menghindar dan mengasingkan diri kalau namanya tidak disebut. Hal ini menunjukkan bahwa IZ mampu melakukan komunikasi yang baik dengan gurunya. Apa yang dilakukan IZ menunjukkan ketercapaian indikator berkembangnya kreativitas yakni memiliki gagasan/ide original dalam mengungkapkan unsur tenaga, menunjukkan antusias dalam melakukan eksplorasi gerak melalui analogi; dan memiliki daya imajinasi yang baik.

Hal menarik lain yang ditunjukkan IZ saat bekerja dalam kelompok adalah saat bercakap-cakap dengan temannya IZ menghindari tatapan mata, namun ia selalu menurut dan mendengar apa yang dikatakan temannya. Empati IZ muncul saat ia memberi dorongan Habib teman sekelompoknya yang diminta guru mencontohkan gerak di depan kelas. Ia berkata: "Jangan malu-malu Bib, ayo maju ke depan". Tugas kelompok telah memotivasi IZ untuk berkomunikasi secara aktif.

Hal ini senada dengan apa yang dijelaskan oleh Kaufman berikut: Instruction tailored to their needs, all students grow to their fullest potential, then the primary challange of teaching in the inclusive environment is to expand and modify our methods and materials to accomodate academically diverse groups of students (Kaufman 2006:11).

Contoh lain yang perlu diungkap adalah gambaran pembelajaran pada pertemuan keempat tahap pengenalan konsep tempo. Menindaklanjuti diskusi dan hasil identifikasi siswa tentang tempo, guru mengajukan beberapa pertanyaan berkaitan dengan hitungan yang diucapkan siswa. Contoh: "Bagaimana ketukan dasar gerakan semut yang membawa beban berat? Anak-anak mulai menghitung. Kemudian guru menanyakan tempo apa itu cepat atau lambat? Siswa menjawab: lambat." Tiba-tiba IZ berinisiatif meragakan gerak semut membawa makanan berat. Gerakan kakinya lambat, kedua tangan diangkat ke atas bahu sambil menunjukkan ekspresi wajah membawa beban berat. Untuk ekspresi tenaga ringan dalam tempo cepat, ia melakukan gerakan tangan yang sama, namun dengan gerak langkah kaki yang lebih cepat. Guru meminta IZ menuliskan di papan tulis apa maksud gerakan yang dicontohkannya. IZ menuruti instruksi guru dan mampu mengungkapkannya dalam tulisan dengan baik. 
Pada pertemuan keempat untuk membantu siswa melakukan kegiatan berkreasi, guru menuliskan sejumlah kode seperti pada Tabel 1 .

Siswa berkelompok dan menyusun gerak dalam tempo yang bervariasi. Mereka terlihat saling membantu dan membimbing agar terjadi keserasian gerak dan tempo. IZ mampu bekerjasama dalam kelompok dan dapat menampilkan gerakan bersama teman lainnya. Pada foto berikut kita bisa melihat perubahan kemampuan bekerjasama yang ditunjukkan IZ dalam kelompok.

Indikator penilaian tentang kreativitas yakni: (1) memiliki gagasan /ide original dalam mengungkapkan unsur gerak tari (tenaga dan tempo); (2) mengembangkan gagasan atau ide terkait unsur gerak; (3) memiliki antusias dalam melakukan eksplorasi gerak melalui analogi; dan (4) memiliki daya imajinasi yang baik muncul secara bertahap sejak pertemuan pertama pada siswa autis maupun siswa lainnya. Perkembangan kreativitas siswa berkembang sejalan berkembangnya kemampuan sosial siswa saat berkomunikasi dalam kelompok. Perkembangan kemampuan bekerja sama, dengan indikator: (1) keterbukaan dengan teman terhadap sesuatu yang baru; (2) bekerja sama dan bertanggung jawab dalam mengerjakan tugas bersama teman; (3) ikut terlibat dalam identifikasi gerak; (4) menyesuaikan diri dalam situasi kebersamaan muncul sebagai perilaku yang tampak pada siswa autis maupun siswa lainnya.

Pada siswa autis perkembangan ini terjadi secara bertahap dan muncul dalam frekuensi yang belum banyak, namun telah menunjukkan perubahan yang signifikan. Indikator berkaitan dengan kemampuan empati, yakni: (1) mengerti perasaan orang lain dan membantu teman yang kesulitan; (2) tertarik untuk belajar bersama teman; (3) merasa senang mengikuti pembelajaran tari; (4) bersikap terbuka dan menerima keberadaan kondisi teman berkembang seiring kegiatan eksplorasi dan berkreasi yang dilakukan secara berkelompok.

Tabel 1. Kode Gerak (Haerani, 2012)

\begin{tabular}{cl}
\hline Kode & \multicolumn{1}{c}{ Makna Gerak } \\
\hline A1 & Gerak semut berbaris dengan menggunakan tempo lambat, tenaga kuat dan mengalir \\
A2 & Gerak semut berbaris dengan menggunakan tempo cepat, tenaga ringan dan mengalir \\
B1 & Gerak semut membawa makanan dengan menggunakan tempo lambat dan tenaga kuat \\
B2 & Gerak semut membawa makanan dengan menggunakan tempo cepat dan tenaga ringan \\
C1 & Gerak semut makan dengan menggunakan tempo lambat dan tenaga kuat \\
C2 & Gerak semut makan dengan menggunakan tempo cepat dan tenaga ringan \\
D1 & Gerak semut bersalaman dengan menggunakan tempo cepat dan tenaga ringan \\
D2 &
\end{tabular}
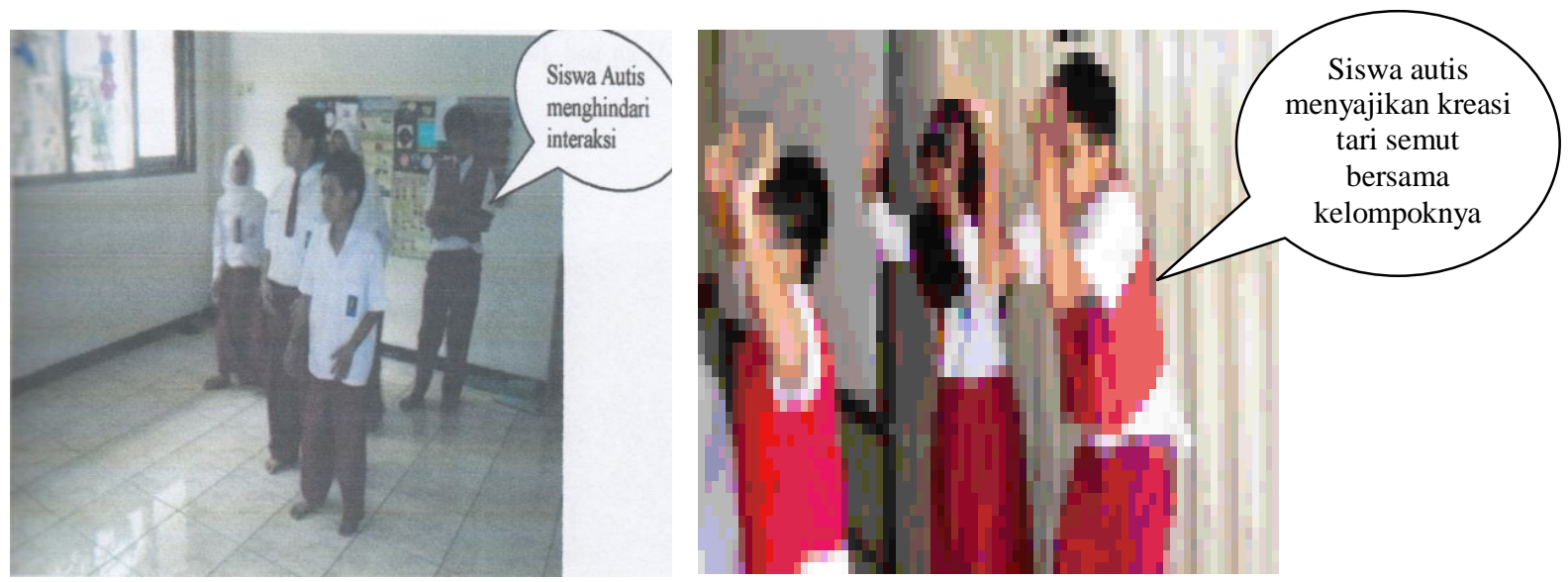

Dokumentasi Reni Haerani (2012) 
Berdasarkan uraian di atas, maka kita melihat adanya perubahan kreativitas dan interaksi sosial siswa autis karena rekayasa lingkungan belajar. Hal ini senada dengan pendapat Munandar (2002:14) bahwa "Kreativitas seseorang mempengaruhi dan dipengaruhi lingkungan dimana mereka berada. Implikasinya kemampuan kreatif dapat ditingkatkan melalui pendidikan".

\section{PENUTUP}

Adaptasi model sinektik dalam pembelajaran seni tari menunjukkan bahwa analogi langsung, analogi personal, dan analogi konflik padat dapat digunakan mulai dari tahap pengenalan konsep, dan eksplorasi. Melalui analogi tersebut muncul gagasan dan ide untuk berekspresi dan berkreasi. Model pembelajaran seni berbasis sinektik ini berimplikasi pada penerimaan siswa autis oleh teman-temannya di sekolah inklusif. Siswa autis mengalami perkembangan kemampuan berkomunikasi dengan guru dan teman sekelasnya. Kombinasi pembelajaran tari secara kelompok dengan bimbingan individual, disertai pendekatan kasih sayang memungkinkan siswa mempercayai guru, dan mau melakukan komunikasi.

Adaptasi model sinektik dalam pembelajaran tari diyakini dapat menjadi salah satu solusi untuk mendorong kreativitas siswa baik secara individu ataupun kelompok. Pembelajaran tari menggunakan adaptasi model sinektik berhasil membantu siswa autis mengembangkan ide kreatif bersama teman-temannya di sekolah inklusif.

\section{UCAPAN TERIMA KASIH}

Penelitian ini merupakan bagian dari penelitian hibah pascasarjana tentang Pengembangan Model Pendidikan Seni bagi Siswa Berkebutuhan Khusus. Melalui hibah pascasarjana yang diberikan oleh DIKTI, kami berkesempatan untuk melakukan kolaborasi dan penelitian bersama dosen dari berbagai disiplin ilmu seni, dosen pendidikan luar biasa, para mahasiswa S2 pendidikan seni dan guru-guru di sekolah yang menjadi lokasi penelitian. Kami ucapkan terima kasih pada DIKTI, rektor UPI,
Pimpinan LPPM UPI, Pimpinan Sekolah, Pascasarjana UPI, Ketua tim penelitian Juju Masunah, Ph.D beserta tim peneliti, Dosen Pendidikan Luar Biasa yang berkenan menjadi nara sumber Ahli, Pimpinan SD Al MabrurBale Endah Bandung beserta guru dan murid kelas V.3. Semoga artikel ini dapat menginspirasi pendidikan seni bagi siswa autis di sekolah lainnya, dan memberi kesempatan pendidikan yang lebih baik bagi siswa autis di sekolah inklusif.

\section{DAFTAR PUSTAKA}

\section{Al Khalili, A.A. 2005. Mengembangkan Kreati- vitas Anak. Jakarta: Pustaka Al-Kautsar.}

Delphie, Bandi. 2009. Pendidikan Anak Autis. Sleman: KTSP.

Hawkins, Alma. M. 2003. Bergerak Menurut Kata Hati: Metoda Baru dalam Menciptakan Tari. Terjemahan I Wayan Dibya. Jakarta: Masyarakat Seni Pertunjukan Indonesia.

Kaufmann, A. Karen. 2006. Inclusive Creative Movement and Dance. United State of America: Human Kinetics.

Masunah, Juju, dkk. 2011. Pengembangan Model Pendidikan Seni Bagi Siswa Berkebutuhan Khusus. Laporan Hasil Penelitian Hibah Pasca Dikti. Bandung: Universitas Pendidkan Indonesia.

Munandar, U. 2002. Kreativitas dan Keberbakatan: Strategi Mewujudkan Potensi Kreativitas dan Bakat. Jakarta: Media Pustaka.

Munandar, U. 2009. Pengembangan Kreativitas Anak Berbakat. Jakarta: Rineka Cipta.

Prasetyono, D.S. 2008. Serba Serbi Anak Autis (Autisme dan Gangguan Psikologi lainnya). Yogyakarta: Diva Press.

Sagala. 2005. Konsep dan Makna Pembelajaran. Bandung: Alpabeta. 
Safaria, Triantoro. 2005. Autisme Pemahaman Baru Untuk Hidup Bermakna Bagi Orang Tua. Yogyakarta: Graha Ilmu.

Veskarisyanti, G. 2008. 12 Terapi Autis Paling Efektif dan Hemat. Yogyakarta: Pustaka Anggrek.
Zhang, J. \& Griffin, A.J. 2007. Including Children With Autism in General Physical Education:Eight Possible Solutions. Jopero 78(3), 33-37. 